and industrial economics. At the North-Western Polytechnic courses are to be held dealing with reading efficiency, report writing and effective speaking. Kingston College of Technology has courses concerning ergonomics and the industrial designer, management problems in the hospital service, introduction to management for architects and problems of top management in the small business. High Wycombe College of Further Education is providing a variety of courses including operations research techniques, advanced organization and methods, analytical training methods, method study and design and marketing management.

\section{Library Services in the United States}

THE February-March issue of Science Information Notes (No. 1, 6; 1964), published by the National Science Foundation, reports the completion of an investigation into automation in research libraries. This indicates that within the next decade automation could augment and accelerate the services rendered by large research libraries in respect of bibliographical processing, catalogue searching and retrieval of documents. Retrieving the intellectual content of books by automatic methods is not now feasible in large collections, but progress would be encouraged by effective automation in cataloguing and indexing functions. The report of another investigation proposes the establishment of a New York library service authority for co-ordinating efforts to improve the services of New York City libraries and tho utilization of joint resources, as well as a programme of research into library activities in the area.

\section{Instrument Applications}

The Shandon Scientific Company, 65 Pound Lane, London, N.W.10, has commenced the free issue of a series entitled Instrument Applications, consisting of publications on modern scientific tochniques. The publications, to be issued at intervals, are numbered consecutively and are to include both original papers and reprints of significant work from various scientific journals. Nos. 1 and 2 in the series wero publishod in December 1963 and are now available on request. They doal with the two-way separation of amino-acids by high-voltage electrophoresis and paper chromatography, and the thin-layer technique of chromatography and electrophoresis, respectively. No. 1 is by J. Ray, M. A. Meyer, A. Deyssohn, J. Frezzal and M. Lamy, and is a reprint from the Revue Française d'Etudes Cliniques et Biologiques. It shows how two-way separations by high-voltage electrophoresis and paper chromatography can be carried out on standard 46-57 cm Whatman filter paper sheots without the use of an expen. sive high-voltago apparatus. No. 2 is by I. Smith and M. J. Smith and is a roprint from Research and Development for Industry. A review is given of the latest developments of the thin-layer technique and the discussion covers advances in the design of apparatus and applications in non-lipid separations.

\section{U.S. National Institute of Dental Research}

Procendings of a scientific seminar marking the fifteenth anniversary of the U.S. National Institute of Dental Research have been published in an attractive brochure (The National Institute of Dental Research, 1948-1963. Pp. iii + 26. Washington, D.C.: Government Printing Office, 1963). The Institute is one of the nine National Institutes of Health which make up the research arm of the U.S. Public Health Service. The publication reproduces addresses of the three main speakers, representing Government science, university research, and the dental profession. The status of dental research and an assessment of accomplishments are reviewed by Dr. S. J. Kreshover, associate director of the National Institute of Dental Research; the role of the National Institute of Dental Research in dental education is presented by Dr.
J. F. Volker, vice-president for health affairs in the University of Alabama; and the communication of research findings is discussed by Dr. L. C. Hendershot, editor of the Journal of the American Dental Association. Addresses by Dr. L. L. Terry, surgeon-general of the Public Health Service, and Dr. J. A. Shannon, director of the National Institutes of Health, are also included. The introduction is by Dr. F. A. Arnold, jun., director of the Dental Institute, who presided over the seminar.

\section{Histochemistry of Dental Tissues}

THE January-March 1963 number of the Annales d'Histochimie (8) is devoted to the histochemistry of the dental tissues, and comprises eleven papers by wellknown workers in this field. There is a useful and fully documented introductory account of recent advances in dental histochemistry, followed by papers on a variety of topics, including the histochemistry of peritubular dentine, the dental granuloma, dental and oral innervation and the developing hamster tooth. Accounts of the electron microscopy of ossification in the jaw of the kitten, and of the autoradiography of dentinal collagen formation, aro also included. Those interested in dental histology and development will find this symposium of value.

\section{University News :}

Birmingham

THE report of the Council of the University of Birming. ham for the year ended December 31, 1963, which includes details of changes in staff during the year, givos the total of full-time academic staff at July 31,1963 , as 678 , including 81 professors and 38 readers (Pp. 30 . Birming. ham: The University, 1964). Details are also given of leave of absence granted during the year. Statistics for students, however, are included in the report of the Vice-Chancellor and Principal (Pp. 39. Birmingham: The University, 1964). Full-time registered student: totalled 4,802 in 1962-63, compared with 4,653 in 1961-62 and 4,160 in 1959-60; for part-time students the corresponding figures are 196, 268 and 206, respectively. Of the full-time students 2,159 men and 237 women were in science, 504 men and 159 women in medicine, and 229 men and 148 women in commerce and social science. While 1,262 full-time students came from homes within 30 miles, 3,022 came from elsewhere in the United Kingdom, 306 from olsewhere in the Common. wealth and 212 from foreign countries; the corresponding figures for $1959-60$ are $1,188,2,611,205$ and $656 ; 432$ resided in halls of rosidence, 2,448 in lodgings and 922 at home. The Vice-Chancellor and Principal's report also comments briefly on some implications of the Robbins Report, referring particularly to the difficulty of increasing the quantity and maintaining the quality of university research in a period of rapid oxpansion. The University proposes to aim at 7,000 students in 1967-68 of whom 3,570 will be in science, 860 in medicine, 590 in commerce and social science, and 300 in the Department of Education. The university library has reflected the general development and the total stock incroased to more than 600,000 volumes. Three new chairs were established in. the applied sciences, in structural, in mechanical and in electrical engineering, and the School of Highway and Traffic Engineering has been detached from the Civil Engineoring Department and converted into an inde. pendent Department of Transportation. Progress in resoarch is described in the thirty-fourth annual report of the University Research Committee, which besides summaries of work in the different departments includes lists of published work and titles of thoses approved for higher degrees (Pp. 161. Birmingham: The University, 1964).

Oxford

A FURTHER report to the Committee on the Relation. ship of the University and Colleges of Oxford by a Sub. 